\title{
SUBJEKTIVITAS DALAM PENAFSIRAN ALQURAN: FENOMENA TAFSIR BERCORAK SEKTARIAN
}

\section{Subjectivity in The Qur'anic's interpreting: The Sectarian Characterized Interpretation Phenomenons}

\author{
Mawardi \\ Institut Agama Islam Negeri Langsa \\ mawardi.msi@gmail.com
}

\begin{abstract}
Tafseer was issued from the desire of mufaseer in revealing the content of Qur'an which aims to answer various problems of life. In this effort, some commentators forced the Qur'an to legitimize opinions and groups. In order for its purpose to be achieved, the mufaseer interpretate (ta'wil) the verses in order to fit the groups and schools followed.
\end{abstract}

Keywords: Subjectivity, Tafseer, Sectarian.

\begin{abstract}
Abstrak
Tafsir Lahir dari keinginan mufasir untuk mengungkapkan kandungan Alquran untuk menjawab persoalan realitas di mana tafsir di hasilkan. Dalam upaya ini, sebagian mufasir memaksa Al-Qur'an untuk melegitimasi pendapat dan kelompoknya. Agar tujuannya tercapai, mufasir mena'wilkan ayat-ayat agar sesuai dengan kelompok dan mazhab yang diikutinya.
\end{abstract}

Kata Kunci: Subjektivitas, Tafsir, Sektarian.

\section{Pendahuluan}

Kajian terhadap Alquran dapat dilakukan dengan melihat berbagai objeknya, mulai dari aspek sejarah kodifikasinya, qirā'ah-nya, sebab-sebab turunnya sampai pada perkembangan penafsirannya. Sedangkan kajian dari aspek penafsirannya justru mengalami perkembangan yang cukup signifikan, sejak diturunkannya Alquran hinggga sekarang. Munculnya berbagai kitab tafsir yang sarat dengan berbagai ragam metode maupun pendekatan, merupakan bukti kongkret bahwa upaya untuk menafsirkan Alquran memang tidak pernah berhenti. Hal ini merupakan keniscayaan sejarah, karena umat Islam pada umumnya ingin selalu menjadikan Alquran sebagai 
mitra dialog dalam menjalankan kehidupan dan mengembangkan peradaban. Proses dialektika antara teks yang terbatas dan konteks yang tak terbatas itulah sebenarnya yang menjadi pemicu dan pemacu bagi perkembangan tafsir.

Tatkala berbicara mengenai perkembangan tafsir, itu artinya juga sedang membicarakan sejarah tafsir dalam berbagai periode dengan paradigma-paradigma pada masanya yang melahirkan berbagai teori penafsiran. Penerapan teori-teori penafsiran telah banyak melahirkan karya-karya tafsir dalam berbagai periode. Kedinamikaan tafsir dan keunikannya menggambarkan keinginan mufasir untuk menjawab problematika yang melingkupi situasi dan kondisi di mana tafsir itu dihasilkan. Ini merupakan suatu keniscayaan sejarah dalam pendialogkan realitas dengan teks. Persoalannya, jika upaya dialektika tetap mengutamakan horizon teks (Alquran), maka mufasir dianggap benar, namun jika pendialogan mengesamping horizon Alquran, maka dianggap pemaksaan keinginan dalam memahami Alquran. Berangkat dari sinilah, penulis tertarik untuk menggambarkan upaya mufasir dalam mengungkapkan makna Alquran yang terlebih dahulu dipengaruhi mazhab dan keilmuan tertentu.

\section{Epistemologi Tafsir Sektarian}

Berbicara persoalan tafsir sektarian, berarti menelaah pengaruh kesubjektifan mufasir dalam memahami dan menafsirkan sesuatu. Sebelum memahami dan menafsirkan suatu teks, seorang mufasir sudah dipengaruhi oleh latarbelakang keilmuan dan ideologi tertentu. Kemudian kondisi tersebut terbawa dalam upayanya memahami teks. Kondisi inilah kemudian lebih dikenal dengan istilah sektarian dalam memahami dan menelaah sesuatu.

Istilah sektarianisme sendiri tidaklah baru dalam proses memahami teks, penggunaannnya sudah sangat banyak, terutama dalam ilmu-ilmu sosial dan keterpengaruhannya terhadap suatu kondisi. Dalam Kamus bahasa Indonesia "sektarian" atau "partisan" diartikan dengan pengikut suatu partai. ${ }^{1}$ Dalam dunia sosial, sektarian dikenal dengan istilah ideologi. Kata ideologi sendiri banyak pengertiannya, tergantung pada penggunaan tujuannya. Namun dalam pengertian yang paling umum dan lunak, ideologi adalah pikiran yang terorganisir, yakni nilai, orientasi, dan kecenderungan yang saling melengkapi sehingga membentuk perspektifperspektif ide yang diungkap melalui komunikasi. Karl Marx (1818-1883) dan Fredrich Engels (1820-1895) melihat ideologi sebagai fabrikasi atau pemalsuan yang digunakan oleh sekelompok orang untuk membenarkan diri mereka sendiri. Karenanya, konsep ideologi tersebut jelas sangat subjektif dan keberadaannya hanya untuk melegitimasi kelas penguasa di tengah keberadaan masyarakat. Masih menurut Marx dan Engels, ideologi atau gagasan politik dominan di setiap masyarakat akan selalu mencerminkan

\footnotetext{
${ }^{1}$ Tim Prima Pena, Kamus Ilmiah Populer,(Jakarta: Gramedia, tt), h.361)
} 
kepentingan dari kelas berkuasa. ${ }^{2}$ Dalam konteks penafsiran Al-quran, istilah "sektarian" itu bisa terlihat dari ungkapanIgnaz Goldziher dalam kajiannya tentangmazhab-mazhab tafsir. ${ }^{3}$ Ignaz Goldziher mengartikan istilah sektarian sebagai upaya umat Islam mencari legitimasi Alquran terhadap keyakinan dan kelompok yang dianutnya.

Istilah sektarian yang dimunculkan oleh Ignaz ini kemudian diikuti oleh intelektual-intelektual muslim. Dalam mengistilahkan tafsir sektarian para intelektual muslim berbeda, tetapi tetap masih dalam pemahaman yang sama. Hasan Hanafi menyebut istilah tersebut dengan tafsir dogmatis. Corak tafsir ini muncul sebagai bagian dari gerakan-gerakan politik dan bercirikan dogmatis. ${ }^{4}$ Nasr Hamid mengistilah tafsir sektarian dengan tafsir talwin, yaitu memberi warna pada teks sesuai dengan pemahaman awal. ${ }^{5}$ Ada berbagai sudut pandang para intelektual dalam mengistilah tafsir sektarian, namun semua mengacu pada sistem penafsiran yang berupaya untuk mencari legalitas mazhab dan ideologi yang mendahului penafsir.

Dari uraian di atas, dapat dipahami bahwa tafsir sektarian memberikan dua pengertian yang saling bertolak belakang. Secara positif dipersepsikan sebagai gambaran dunia (world view) yang menyatakan kelompok-kelompok sosial tertentu untuk membela dan memajukan kepentingan-kepentingan mereka. Sedangkan secara negatif dipersepsikan sebagai kesadaran palsu, yaitu suatu kebutuhan untuk melakukan penipuan dengan cara memutarbalikkan pemahaman terhadap Alquran yang ditafsirkan.

Jika ditelaah secara epitimologi, kehadiran tafsir yang bercorak sektarian merupakan dampak dari upaya mufasir mengajak Alquran sebagai teks suci untuk berdialektika dengan konteks budaya yang berkembang pada saat itu.Oleh karena perkembangan budaya tidak pernah terbatas yang harus dijawab dengan teks yang terbatas, maka kehadiran tafsir dengan berbagai corak kesektarian akan terus bermunculan untuk menjawab ketidakpuasan mufasir terhadap tafsir-tafsir sebelumnya dengan mengikutsertakan budaya dan latarbelakangnya. Memang tidak selamanya tafsir yang bercorak sektarian dianggap negatif, karena budaya yang melingkupi mufasir tidak harus "memaksa" teks-teks Alquran sesuai dengan keinginannya. Maka tidak heran jika tafsir Alquran menjadi jangkar bagi teolog sektarian dan skolastik untuk menguatkan berbaai doktrin mereka. ${ }^{6}$

\footnotetext{
${ }^{2}$ BagusTakwin, Akar-akarIdeologi, PengantarKajianKonsepIdeologi Dari Plato Hingga Bourdieu, (Yogyakarta: Jalasutra, 2003), h. 17

${ }^{3}$ Ignaz Goldziher, MazhabTafsir; dariKlasikhingga Modern, Terj. M. AlaikaSalamullah, dkk., (Yogyakarta: eLSAQ Press, 2006), h. 4

${ }^{4}$ Hasan Hanafi, MetodeTafsirdanKemaslahatanUmat, (Yogyakarta: Nawesea, 2007), h. 37

${ }^{5}$ Nashr Hamid Abu Zayd, KritikWacana Agama, Terj. KhoironNadhiyyin, (Yogyakarta: LKiS, 2003), h. $120-121$

${ }^{6}$ Lihat Budi Juliandi dan Saifuddun Herlambang, "Menggugat Tafsir Tekstual”, Jurnal At-Tibyan, $\begin{array}{lllll}\text { Vol. I } & \text { Nomor } & 1 & \text { (Juni } & \text { 2016), } \\ \text { h. }\end{array}$ 49http://http://journal.iainlangsa.ac.id/index.php/tibyan/article/view/32diakses tanggal 17 Juni 2018
} 
Berkaitan dengan hal tersebut, Nạssr Hamīd Abū Zayd menawarkan agar pembedaan dalam menafsir teks antara makna (dalālah) dengan signifikansi (maghzā) harus menjadi tuntutan utama agar batas-batas antara masalalu dan masa kini tidak mencair di satu sisi, dan agar metodologi tafsir tidaktunduk pada ideologi pengkaji secara serampangan dan vulgar. Di sisi lain, apabila interaksi dan interpretasi dilakukan secara serampangan dan vulgar, dalam kerangka ideologis, maka akan mengabaikan gerak teks dalam konteks historisnya di satu sisi, dan akan menolak fakta-fakta dan data-data yang menjadi media bagi terungkapnya makna teks, di sisi lain. Sikap ceroboh dalam berinteraksi dengan teks dan dalam menginterpretasikannya biasa terjadi dalam kondisi ketika pengkaji tidak menyadari, atau mengabaikan ideologinya.. Hal inilah yang menyebabkan ideologi itu menjalankan perannya secara tersembunyi tanpa pengawasan, tanpa aturan atau kendali. Dalam kondisi seperti ini akan sangat mudah terjadi loncatan dari tafsir ke talwin (ideologisasi), dan batas-batas antara makna dan signifikansi menjadi mencair. ${ }^{7}$

Selain itu, Nasruddin Baidan juga menawarkan beberapa kepribadian yang harus ada pada mufasir. Adapun kepribadian tersebut meliputi ikhlas, netral, dan sadar ${ }^{8}$. Ikhlas merupakan membebaskan diri dari intervensi pihak-pihak lain selain Allah. Seorang mukhlis dalam menafsirkan Alquran tidak berharap apapun dari penafsirannya kecuali ridha Allah. Jika tidak, maka tafsir yang dihasilkan tidak lebih dari melegalkan dan menuruti kelompok yang diikutinya. Sedangkan netral adalah tidak boleh memihak kepada pendapat siapapun kecuali Alquran. Dalam proses penafsiran mufasir harus melepaskan diri sebebas-bebasnya dari berbagai keterikatan yang akan mencapai petunjuk yang diberikan Allah dalam ayat yang ditafsirkan. Sebagaimana ditegaskan oleh Abū 'Alā al-Mawdūdi, persyaratan netral merupakan kriteria utama yang harus dimiliki oleh mufasir. ${ }^{9}$ Dalam pengertian yang lain, netral meninggalkan horizon mufasirdengan lebih mementingkan horizon teks Alquran. Dengan demikian, Alquran tidak dipaksakan untuk menuruti pemahaman yang melingkupi dunia mufasir, melainkan membiarkan Alquran berbicara dengan sendirinya. Adapun sadar merupakan kesadaran mufasirakan keautentikan Alquran sebagai firman Allah. Dengan demikian, tanggungjawab sebagai mufasiruntuk tidak memutarbalikkan pemahaman ayat semakin besar. Sebab merubah pemahaman Alquran berarti merubah firman Allah, merubah firman Allah sama dengan mendustakan Allah.

Ketiga hal tersebut harus dimiliki oleh seorang mufasir agar tidak terjadi penyimpangan-penyimpangan dalam menafsirkan Alquran sehingga seseorang yang ingin menafsirkan Alquran dapat mengetahui sepenuhnya dampak negatif yang terjadi sebagai konsekuensi logis dari tidak dimilikinya keperibadian yang baik sebagai seorang interpreter kitab suci.

\footnotetext{
${ }^{7}$ Nashr Hamid Abu Zayd, KritikWacana Agama, Terj. KhoironNadhiyyin, (Yogyakarta: LKiS, 2003), h. $120-121$

${ }^{8}$ NashruddinBaidan, WawasanBaruIlmuTafsir, (Yogyakarta: PustakaPelajar, 2005), h. 355.

${ }^{9} \mathrm{Abu}$ Al-'Ala al-Mawdudi, Mabadi' Asasiyyat li Fah Alquran, terj. Khalil Ahmad al-Hamidi, cet. Ke2, (Jakarta: Al-Majlis al-'Ala al-Indunisi li al-Da'wat al-Islamiyyat, 1999), h. 14, 48
} 


\section{Sejarah Muncul Tafsir Sektarian}

Secara umum, perkembangan tafsir sektarian dalam paradigma penafsiran Alquran tidak terlepas dari kemunculan mazhab dalam Islam. itu bermula ketika terjadi pergolakan antara Ali dan Muawiyah yang berakhir dengan perang siffïndan mencapai puncaknya pada masa afirmatif. ${ }^{10}$

Perkembangan tafsir pada era afirmasi berbasis pada nalar ideologis. ${ }^{11}$ Ini terjadi pada abad pertengahan. Tafsir pada periode ini muncul dalam situasi ketegangan antar disiplin ilmu sebagai konsekuensi dari zaman keemasan ilmu pengetahuan di dunia Islam. Bahkan dalam kondisi ketegangan antar kelompok dalam masing-masing disiplin ilmu pengetahuan Islam. Dengan kata lain, tafsir pada periode ini dilatarbelakangi oleh "kepentingan" mufassirnya yang notabene pendukung atau peminat disiplin ilmu atau pola berpikir tertentu dalam masing-masing disiplin ilmu. ${ }^{12}$

Konsekuensinya, produk tafsir yang dihasilkan periode ini memiliki karakter khusus sebagai akibat dari paradigma sektarian yang membelenggu mufasirnya. Hal ini sangat mungkin terjadi, lantaran mufassirnya yang tampil pada periode ini sebelum memulai menafsirkan Alquran terlebih dahulu menjatuhkan pilihan menekuni disiplin ilmu-ilmu tertentu atau menjatuhkan pilihan untuk mendukung mazhab-mazhab tertentu. Seperti al-Farā' adalah ahli disiplin ilmu bahasa dan guru beberapa pangeran Abbasiyah pendukung Mu'tazilah. Ibn Jarir al-Tabari disamping sebagai tokoh sejarawan muslim, secara teologis, dia posisinya mirip al-Asy'ari yang cenderung mengambil jalan tengah antara ahli hadis dan rasionalis Mu'tazilah. Az-Zamakhsyari adalah ahli bahasa dan sastra yang terlahir di daerah basis Mu'tazilah sehingga ikatan emosionalnya dengan Mu'tazilah tidak dapat disangkal. ${ }^{13}$ Masih dalam wilayah tafsir bernuansa teologis tetapi dari aliran lain tampil Fakhruddin ar-Rāzí, seorang mutakallimin Asy'ariah yang ahli juga dalam bidang filsafat. Dari kelompok ini juga tampil al-Baidawi yang berusaha merespon capaian az-Zamakhsyari dari ar-Razi.

Adapun dari pendukung fiqih beserta madzhab-madzhabnya, muncul al-Kiyā' alHarasī dari madzhab Syāfi'i, al-Qurțubi dan Ibnu'Arabi propagandis teori wahdatul wujud dalam tasawuf. Di kalangan filosof juga tampil ahli-ahli filsafat Islam yang berkepentingan untuk menjustifikasi gagasan filsafatnya dengan menafsirkan ayat-ayat Alquran tertentu. Tokoh tasawuf praktis diwakili oleh al-ĀLūsi pendukung tarikat Naqsyabandiah. Dari kalangan Syi'ah tampil Mullā Mụsin al-Rasyi, Abū'Ali aṭṬabarsi, juga al-Syaukanì yang mewakili teologi Syi'ah Zaidiyah. Dari para ahli kisah

10 Abdul Mustaqimmembagisejarahperkembangantafsirdalamtigabentuk, yaitu: formatif, afirmatif, danreformatif. periode formatif merupakan periode pertama perkembangan tafsir, yaitu masa Nabi, sahabat dan tabi'in. Periode Afirmatif, perkembangan tafsir pada era afirmasi berbasis pada nalar ideologisdan ini terjadi pada abad pertengahan. Periode reformasi, periode ini berangkat dari paradigma yang terdapat pada periode afirmasi, yaitu kegelisahan para modernis mengenai tafsir-tafsir yang berkembang pada masa pertengahan.Lihat, Abdul Mustaqim, Aliran-aliran Tafsir dari Periode Klasik hingga Kotemporer, (Yogyakarta: Kreasi Wacana, 2005), h. 32

${ }^{11}$ Abdul Mustaqim, Aliran-aliran Tafsir dari Periode Klasik hingga Kotemporer,h.59

${ }^{12}$ Abdul Mustaqim, Aliran-aliran Tafsir dari Periode, h. 75

${ }^{13}$ Abdul Mustaqim, Aliran-aliran Tafsir dari Periode, h. 76 
atau ahli atsar ada Ibnū Katsīr, al-Tsa'labì. Demikian dengan ahli sastra ada Abū Hayyān, Jalāluddīn al-Mạ̣alli, al-Naisaibūrí, al-Qạ̣i 'Abdul Jabbār dan masih banyak lagi mufasir yang memiliki disiplin ilmu tertentu.

Kecenderungan mazhab dalam menafsirkan Alquran lahir pada periode afirmasi atau disebut dengan periode pertengahan karena pada periode ini sudah banyak berkembangnya mazhab-mazhab. Adapun latarbelakang munculnya madhāhib al-tafsìr, sesungguhnya merupakan sebuah keniscayaan sejarah, sebab setiap generasi ingin selalu "mengkonsumsi" dan menjadikan Alquran sebagai pedoman hidup, bahkan dijadikan sebagai legitimasi bagi tindakan dan perilakunya. Ignaz Goldziher menyatakan bahwa setiap aliran pemikiran yang muncul dalam sejarah umat Islam selalu cenderung untuk mencari legitimasi dan justifikasi dari kitab sucinya (Alquran). ${ }^{14}$ Dengan begitu, pemikiran tersebut akan mendapat posisi yang kuat di hati para pengikutnya dalam sistem keberagamaan mereka.

Untuk lebih jelas tentang sebab-sebab muncul mazhab-mazhab tafsir, maka di sini penulis memaparkan beberapa faktor yang mendukung kemunculannya. Faktorfaktor tersebut secara umum dapat dikategorikan dalam dua bagian, yaitu faktor internal dan faktor eksternal. ${ }^{15}$ Factor intern adalah sebab yang ditimbulkan dari Alquran sendiri, yaitu; Pertama, kondisi objektif teks Alquran yang memungkinkan untuk dibaca secara beragam. Kedua, kata-kata dalam Alquran yang memungkinkan untuk ditafsir secara beragam, seperti kata "dharaba"16. Ketiga, adanya ambiguitas makna dalam Alquran, dengan adanya hal-hal yang musytarak (bermakna ganda), seperti kata-kata al-Qurū' (dapat diartikan dengan suci dapat pula diartikan haid). Demikian pula kata-kata yang dapat diartikan hakiki dan majazi, seperti kata-kata "lamasa" dalam ayat "17 dapat berarti menyentuh dan dapat pula berarti jimak. Sedangkan faktor eksternal merupakan sebab yang datang dari luar Alquran, seperti kondisi subjektif mufasir sendiri yang didukung oleh sosio kultural, politik, dan lain-lain.

Jadi, walaupun Alquran sendiri memberikan peluang untuk ditafsir bermacammacam, bukan berarti Alquran harus mengikuti keinginan kelompok tertentu atau untuk membenarkannya sehingga Alquran hanya dapat dikonsumsi oleh suatu kelompok dan tidak untuk kelompok yang lain. Dengan kata lain, Alquran yang diyakini sebagai "Rahmatan lil 'alamin" berubah fungsi menjadi ideologi kelompok tertentu. Fenomena inilah yang terjadi di abad afirmasi(pertengahan), kemunculan mazhab dan firqah-firqah dalam beragama menjadi lahan empuk untuk menjadikan Alquran sebagai legalitas. Menurut Hamim Ilyas dalam kata pengantar buku "Studi Tafsir" menyatakan: masa afirmasi merupakan masa perkembangannya teori yang

\footnotetext{
${ }^{14}$ Ignaz Goldziher, Mazhab-mazhab Tafsir, terj. M. Alaika Salamullah, dkk, (Yogyakarta:Elsaq, 2006), h.3.

${ }^{15}$ Ignaz Goldziher, Mazhab-mazhab Tafsir, h.12.

${ }^{16}$ Q. S. An-Nisa': 34

${ }^{17}$ Q. S. al-Maidah: 6.
} 
dibangun di atas paradigma legitimasi Alquran. ${ }^{18}$ Oleh karena itu,bermunculnya tafsir bercorak partisan ${ }^{19}$.

Jika dikaitkan perkembangan tafsir era afirmasi dengan legitimasi mazhab, maka dapat dipastikan tafsir bercorak partisan muncul dikalangan para fanatisme. Sedemikian tingginya fanatisme salah satu golongan terhadap mazhabnya, hingga lahirlah kecenderungan taqlid yang menghapuskan toleransi, dan cara berpikir kritis generasi tertentu. Ironisnya, mereka tidak segan-segannya merubah teks wahyu yang rahmatan lil alamin untuk kepentingan kelompok atau politik mereka.

Meskipun Alquran ditafsirkan kelompok sektarianisme tanpa mengindahkan horizon teks, namun mereka mempunyai suatu metode memahami Alquran agar sesuai dengan pemahaman dan keinginannya. Metode yang mereka gunakan adalah takwil. Pengunaan takwilsebagai metode dilatarbelangi oleh suatu asumsi "apabila ada ayat yang tidak sesuai dengan keinginan mereka, maka ayat itu ditakwilkan". Sebagaimana yang dikatakan oleh al-Karkhi (seorang yang sangat fanatik terhadap mazhabnya);

$$
\text { كل أية أو حديث يخالف ما عليه أصحابنا فهو مؤول أو منسوخ }
$$

Artinya: "Tiap-tiap ayat atau hadits yang bertentangan dengan pendapat pendukungpendukung mazhab kami, maka ayat atau hadits itu harus ditakwilkan atau dinyatakan mansukh"

Dari penyataan al-Kharki tersebut dapat difahami bahwa takwil merupakan senjata ampuh yang mereka gunakan untuk menafsirkan Alquran semaunya atau bagaimana kehendak dari mazhabnya. Meskipun begitu, seorang mufasirdapat membebaskan diri agar tidak terjebak dalam penggunaan takwil versi sektarianisme.

\section{Contoh Takwil yang digunakan}

Sebagaimana telah disebutkan di atas bahwa metode yang sangat mendukung tercipta tafsir partisan adalah takwil. Takwilpada dasarnya bukanlah metode yang harus dihindari dan ditakutkan. Penggunaan takwildalam memahami ayat terkadang sangat diperlukan. Sebab ada ayat yang tidak terjawab hanya menggunakan tafsir. Apalagi ayat-ayat Alquran sendiri terdiri dari mụkkamāt dan mutasyābihāt. Khusus ayat-ayat mutasyābihāt yang menjelaskan penyerupaan Tuhan dengan makhluk itu sangat perlu digunakan metodetakwil, sehingga bentuk tasybīh dapat di tahzih. Misalnya, "yadullāh fauqa aidihim", kata "yadun" secara literal diartikan "tangan". Jika kata "yadun" tetap diartikan "tangan", maka pemahaman yang akan muncul adalah Allah mempunyai tangan sebagaimana tangan manusia dan itu merupakan bentuk pen-

\footnotetext{
${ }^{18}$ Muhammad Yusuf,ddk., StudiKitabTafsir (MenyuarakanTeks yang bisu), (Yogyakarta: Teras, 2004), h. ix

${ }^{19}$ Partisan secara etimologi; pengikut suatu partai. (Lihat: Tim Prima Pena, Kamus Ilmiah Populer,(Jakarta: Gramedia, tt), hal.361). Sedangkan arti Partisan dalam tafsir ialah cara menafsirkan Alquran untuk kepentingan kelompok.(Lihat: Muhammad Yusuf, dkk, Studi Kitab Tafsir,..., h. x)
} 
tasybīh-an Allah dengan manusia. Untuk dapat merubah tasybìh menjadi tanzih, maka kata "yadun" dalam ayat ini ditakwilkan menjadi "kekuasaan".

Persoalannya, bagaimana corak ta'wil yang boleh dan tidaknya digunakan dalam memahami ayat Alquran sehingga tidak terjebak dalam bentuk sektarian. Menjawab persoalan ini, ulama tafsir mensyaratkan pentakwilan ayat Alquran harus didukung oleh ayat-ayat yang lain. ${ }^{20}$ Di samping itu, syarat lain dalam mengaplikasikan takwil, mufasirharus memahami dengan benar ketentuan-ketentuan ulum Alquran, seperti memahami nāsikh wa al-mansūkh, asbāb al-nuzūl, dan ketentuan-ketentuan lain yang merupakan bagian dari proses penerimaan Alquran. Jika seorang mufasir tidak mengindahkan persyaratan tersebut, maka tafsir yang dihasilkan bercorak partisan.

Sebagaiman telah dijelaskan sebelumnya, tafsir partisan dilatarbekalangi oleh upaya mufasirmembenarkan mazhab atau gagasannya. Dengan demikian, dapat disimpulkan bahwa tafsir bercorak partisan muncul dikalangan para pengikut mazhabmazhab yang fanatik, baik mazhab kalam, mazhab fiqh, maupun para sufi. Untuk lebih jelasnya tentang cara mereka menafsirkan Alquransehingga timbulnya tafsir partisan dapat dilihat dari beberapa mazhab berikut ini:

Pertama, mazhab kalam. Mazhab ini merupakan kelompok yang lahir dari perdebatan-perdebatan dalam membahas tentang ketuhanan. Kemunculan mazhab ini dipicu oleh persoalan politik yang menyangkut pembunuhan Utsmān bin 'Affān yang berbuntut pada penolakan Mu'āwiyah atas kekhalifahan 'Ali bin Abi Ṭălib. Ketegangan antara 'Ali dan Mu'āwiyah mengkristal menjadi perang siffin. ${ }^{21}$ Pasca pergolakan inilah kemudian muncul firqah-firqah dikalangan umat Islam. dampak yang timbu dari akibat ketegangan ini adalah truth claim (klaim-klaim kebenaran) ditiaptiap firqah. Agar kebenaran mereka diterima dan mendapat pendukung yang banyak, salah satu upaya yang mesti dilakukan adalah dengan mendapatkan legitimasi dari Alquran maupun Hadis.

Inilah yang dilakukan oleh simpatisan atau pengikut mutakallimūn tertentu yang cenderung menafsirkan ayat-ayat Alquran untuk membenarkan mazhab yang dianutnya. Hal itu dapat dilihat dari cara mereka menafsirkan ayat-ayat yang menerangkan tentang kalam. Seperti dalam tafsir al-Kasysyāf karangan al-Zamakhsyari yang didominasi oleh pendapat Mu'tazilah menafsirkan QS. al-An'am ayat 103:

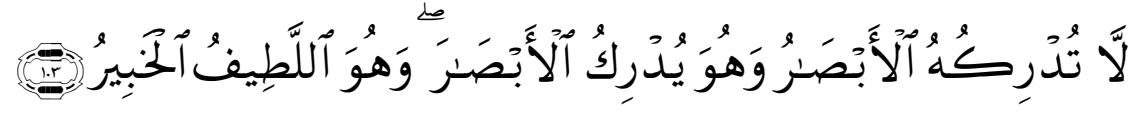

Artinya: "Dia tidak dapat dicapai oleh penglihatan mata, sedang Dia dapat melihat segala yang kelihatan; dan Dialah yang Maha Halus lagi Maha mengetahui”. (Q.S. Al-An'am [6] : 103)

Menurut al-Zamakhsyari, ayat ini sebagai penjelasan bahwa Tuhan tidak dapat dilihat dengan mata kepala sampai kapanpun. Lafad nafi (la) yang terdapat pada ayat

\footnotetext{
${ }^{20}$ NashruddinBaidan, WawasanBaruIlmuTafsir, h. 71

${ }^{21}$ Abdul Razak\&Rosihan Anwar, IlmuKalam, (Bandung: PustakaPelajar, 2006), h. 27-28
} 
tersebut berlaku umum, tidak terkait waktu dan tempat tertentu, baik di dunia maupun di akhirat. Seperti dalam QS. Al-Qiyamah: 22-23

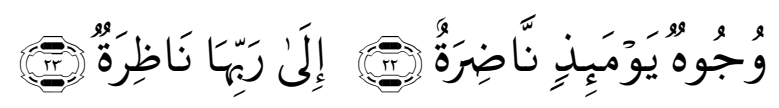

Artinya: "Wajah-wajah (orang-orang mukmin) pada hari itu berseri-seri. 23. Kepada Tuhannyalah mereka melihat”. (QS. Al-Qiyamah [75] : 22-23).

Zamakhsyari berpendapat bahwa karena Tuhan bersifat immateri, maka tidak dapat dilihat dengan mata kepala. Kata nadirah diartikan oleh Zamakhsyari dengan altawaqqu wa al-rajā', (penantian dan pengharapan). Allah adalah esa, dan tidak ada sesuatu apapun yang menyerupainya. Dia bukan jisim (materi), tidak bertubuh, tidak berbentuk, tidak berdaging, tidak berdarah, tidak adanya warna, rasa, panas, dingin, basah, dan lain-lain yang merupakan sifat makhluk. Semua pendapat al-Zamakhsyari tersebut sesuai dengan pendapat Muktazilah, karena Muktazilah menolak paham beautific vision pada sifat Tuhan, menurut Muktazilah Tuhan bersifat immateri, sedangkan mata manusia adalah bersifat materi. Yang imateri hanya bisa dilihat oleh yang imateri. ${ }^{22}$ Untuk menjustifikasikan pendapat kelompoknya, al-Zamakhsyari tidak segan-segannya mengkafirkan kelompok lain.

Berbeda dengan tafsir al-Zamakhsyari, dalam tafsir Jalālain dijelaskan bahwa:"para hari kiamat Allah dapat dilihat", sebagai yang tersebut di bawah ini:

$$
\text { \} إلى رَبِّهَا نَاظِرَةُّهُ أي يرون الله سبحانه وتعالى في الآخرة . }
$$

Pendapat yang ada dalam tafsir Jalālain itu juga didominasi terhadap mazhab yang dianutnya, yaitu mazhab Asy-'Ariyah, karena menurutnya Tuhan tidak dapat dilihat didunia, tapi bisa dilihat di akhirat. ${ }^{23}$

Tafsir al-Mafātih karangan al-Rāzì juga bisa ditemukan kecendrungan al-Razì sendiri dengan Asy-'Ariyah, sehingga ketika dia mengembangkan diskusi tentang kepemimpinan umat Islam pasca Nabi atau imam Abu Bakar, ${ }^{24}$ Justru dalam penafsirannya atas ayat ketujuh dari surat al-Fatihah.

Al-Rāzì menafsirkan ayat tersebut dengan mengaitkan ayat lain, yakni dalam QS. an-Nisa' ayat 69 ,

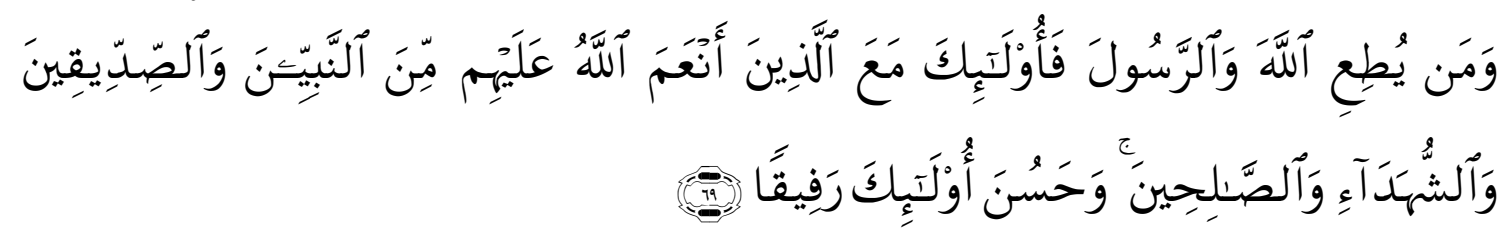

Artinya: "Dan barangsiapa yang mentaati Allah dan Rasul(Nya), mereka itu akan bersama-sama dengan orang-orang yang dianugerahi nikmat oleh Allah, yaitu: Nabi-nabi, para shiddiiqiin, orang-orang yang mati syahid, dan orang-

\footnotetext{
${ }^{22}$ Abi al-Qasim Jabir Allah Mahmud Ibn Umar al-Zamakhsyari al-Khaurazi, Tafsir al-Kasyaf an Haqaiq al-Tanzil wa Uyun al-Aqwil fi Wujuh al-Ta'wil, (Beirut: Dar Al-Maarif, 2009), h. 1162

${ }^{23}$ Jalaluddin Al-MahallidanJalaluddin As-Suyuti, TafsirJalalain, (Semarang: Toha Putra, t.th), h. 129

${ }^{24}$ Muhammad al-Razi Fakhruddin, Tafsir al-Fakhri ai-Razi, Juz 1, (Beirut: Dar al-Fikr, 1981), h. 223
} 
orang saleh. dan mereka Itulah teman yang sebaik-baiknya”. (QS. an-Nisa' [4]:69).

Dia menyatakannya sebagai berikut; "tidak diragukan lagi bahwa pemuka alShiddiqin adalah Abu Bakar. Oleh sebab itu, ayat ini mengandung pengertian bahwa Allah telah memerintahkan kita agar mencari hidayah yang sama dengan yang diperoleh Abu Bakar dan para shiddiqun yang lain. Kalau Abu Bakar itu orang zalim niscaya tidak dibenarkan untuk menjadi panutan. Oleh sebab itu, tidak dapat disangkal bahwa ayat ini menunjukkan imamah Abu Bakar". Betapapun al-Rāzi memasang ayat 69 untuk menjelaskan surat al-Fatihah ayat 7, namun sebenarnya hal itu hanya sebagai justifikasi saja, sebab terlalu jauh korelasi antara ayat 7 dalam surat al-Fatihah dengan ayat 69 dalam surat an-Nisa'. Terlebih jika ditarik-tarik pada persoalan politik yaitu imāmāh Abu Bakar.

Begitu juga halnya dengan kelompok syiah, mereka menafsirkan ayat Alquran didominasi untuk kepentingan mazhabnya, yaitu tentang imamah'Ali bin Abì Ṭālib dan keluarganya. Sebagaimana Abū Ja'far menafsirkan QS Ibrahim ayat 24-26,

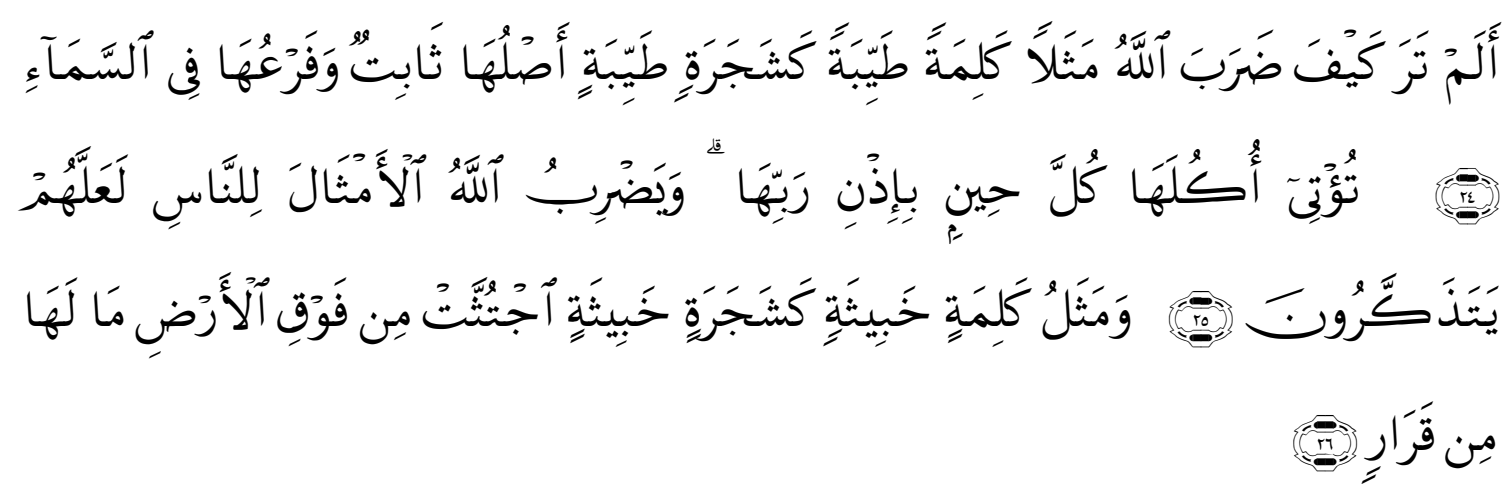

Artinya: "Tidakkah kamu perhatikan bagaimana Allah Telah membuat perumpamaan kalimat yang baik seperti pohon yang baik, akarnya teguh dan cabangnya (menjulang) ke langit. Pohon itu memberikan buahnya pada setiap musim dengan seizin Tuhannya. Allah membuat perumpamaan-perumpamaan itu untuk manusia supaya mereka selalu ingat. Dan perumpamaan kalimat yang buruk seperti pohon yang buruk, yang Telah dicabut dengan akar-akarnya dari permukaan bumi; tidak dapat tetap (tegak) sedikitpun”. (Q.S. Ibrahim [14] : 24-26)

Dalam menafsirkan ayat ini, Abū Ja'far berkata:"pohon itu adalah Rasulullah, nasabnya (keturunannya) ditetapkan dikeluarga Bani Hasyim, cabang pohon itu adalah Ali bin Abi Thalib, dahan pohon itu adalah Fatimah, buah pohon itu adalah keturunan Ali dan Fatimah, dan para pengikut Syiah. Sedangkan makna dari "pohon yang buruk, yang Telah dicabut dengan akar-akarnya dari permukaan bumi; tidak dapat tetap (tegak) sedikitpun" adalah mereka orang kafir yang amalnya tidak bisa naik kelangit dan Bani Umayyah yang tidak pernah mengingat Allah dalam sebuah majelis, dan tidak pula di dalam mesjid. Tidak ada amal perbuatan mereka yang bisa naik kelangit kecuali hanya amal sedikit orang 
تب يد أبى لهب mereka. ${ }^{25}$ Begitu juga halnya dengan Kaum Rafidhah dalam menafsirkan dengan Abu Bakar dan Umar, karena menurut mereka kedua khalifah tersebut sudah merebut kekhalifahan dari tangan Ali bin Abi Thalib. ${ }^{26}$ Selain menakwilkan ayat Alquran sesuai dengan maksud mazhab mereka, lebih ironis lagi mereka merubah kalimat yang ada dalam ayat tersebut. Seperti menggantikan kalimat "illa", dengan "wala" dalam QS alBaqarah ayat 150 ,

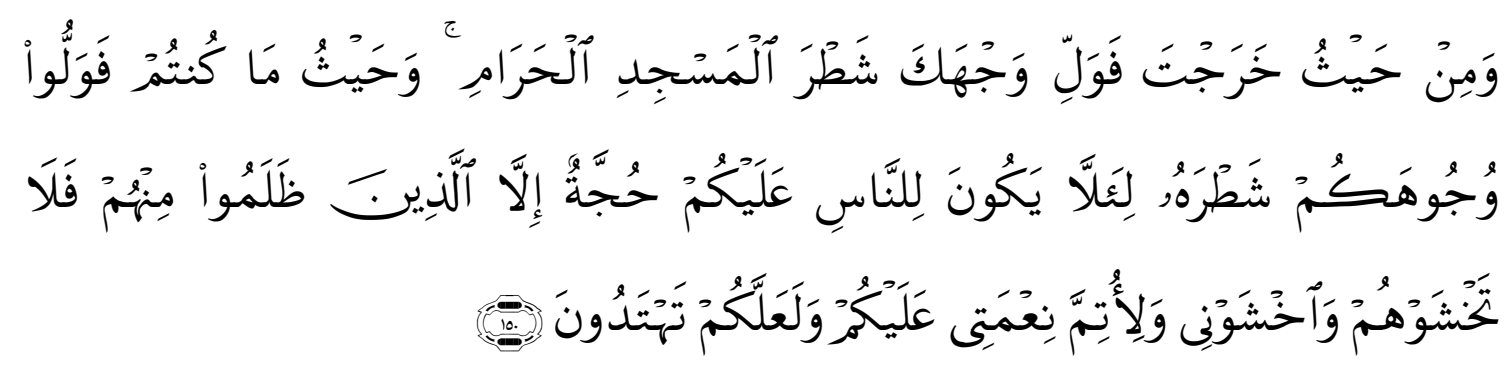

Artinya: “dimana saja kamu (sekalian) berada, Maka palingkanlah wajahmu ke arahnya, agar tidak ada hujjah bagi manusia atas kamu, kecuali orang-orang yang zalim diantara mereka”. (Q.S. Al-Baqarah [2] :150).

Mereka mengartikan ayat tersebut dengan: "Dan bukanlah orang-orang yang zalim diantara mereka".

Serta QS al-Nisa' ayat 92:

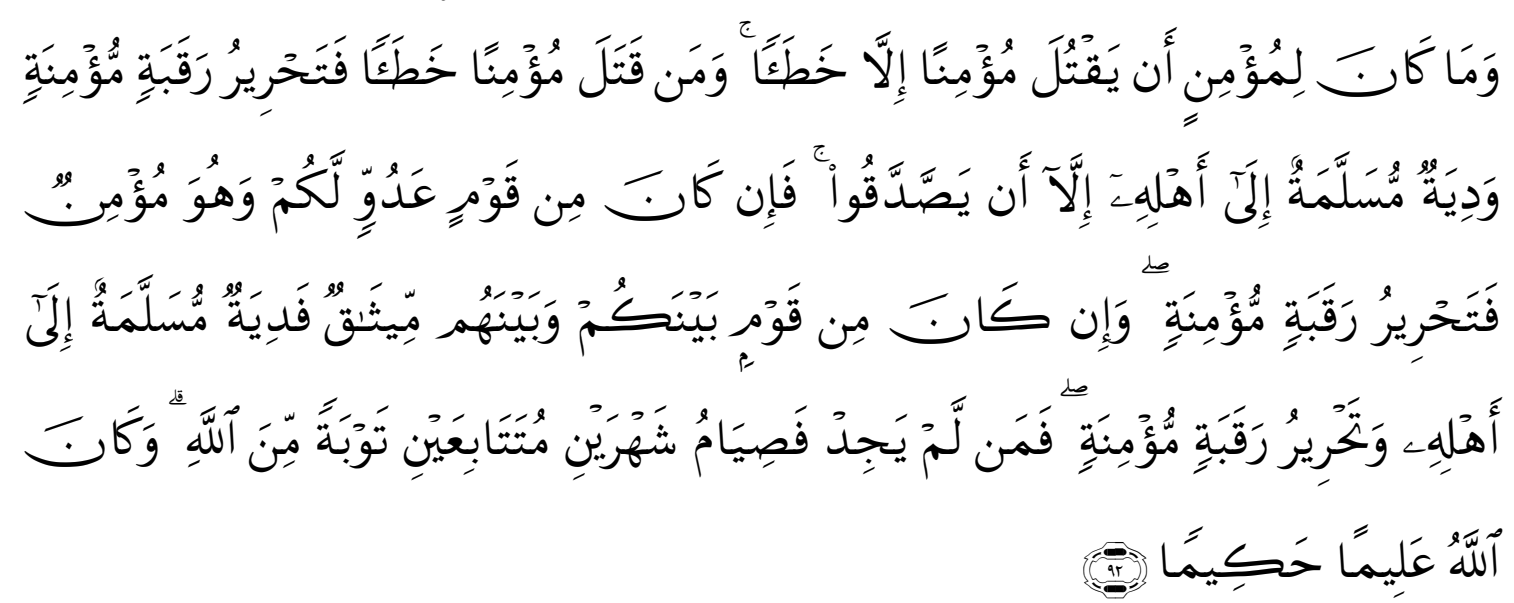

Artinya: "Dan tidak layak bagi seorang mu'min membunuh seorang mu'min [yang lain], kecuali karena tersalah [tidak sengaja], dan barangsiapa membunuh seorang mu'min karena tersalah [hendaklah] ia memerdekakan seorang hamba sahaya yang beriman serta membayar diat yang diserahkan kepada keluarganya [si terbunuh itu], kecuali jika mereka [keluarga terbunuh] bersedekah. Jika ia [si terbunuh] dari kaum yang memusuhimu, padahal ia mu'min, maka [hendaklah si pembunuh] memerdekakan hamba-sahaya yang mu'min. Dan jika ia [si terbunuh] dari kaum [kafir] yang ada perjanjian [damai] antara mereka dengan kamu, maka [hendaklah si pembunuh] membayar diat yang diserahkan kepada keluarganya [si terbunuh] serta

\footnotetext{
${ }^{25}$ Ignaz Goldziher, Mazhab-mazhab,..,h. 366

${ }^{26}$ NashruddinBaidan, WawasanBaruIlmu,...h. 68.
} 
memerdekakan hamba sahaya yang mu'min. Barangsiapa yang tidak memperolehnya, maka hendaklah ia [si pembunuh] berpuasa dua bulan berturut-turut sebagai cara taubat kepada Allah. Dan adalah Allah Maha Mengetahui lagi Maha Bijaksana”. (Q.S. Al-Nisa' [4] : 92).

Mereka mengartikan dengan: " Dan tidak layak bagi seorang mukmin membunuh seorang mukmin (yang lain), dan bukanlah masalah. ${ }^{27}$

Selain itu, corak partisan juga dapat dilihat dalam penafsiran kelompok syiah ghulat. Misalnya dalam memahami QS. Al-Baqarah ayat 19,

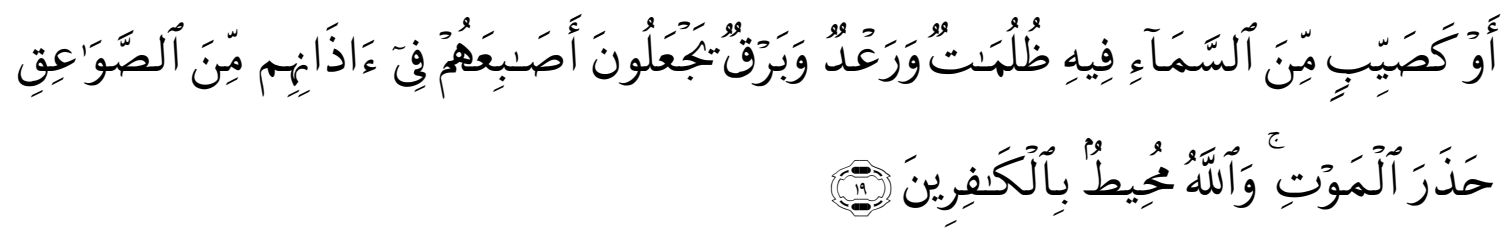

Artinya:"atau seperti (orang-orang yang ditimpa) hujan lebat dari langit disertai gelap gulita, guruh dan kilat; mereka menyumbat telinganya dengan anak jarinya, karena (mendengar suara) petir,sebab takut akan mati. dan Allah meliputi orang-orang yang kafir. (Q.S. Al-Baqarah [2] : 19).

Abdullah ibn Saba'28 menafsirkan kata "رعد (صوت على) suara Ali" dengan kata "برق) ditafsirkan dengan "(سوط) cambuk". Jika (kelompok Abdullah bin Saba') mendengar petir, mereka akan mengatakan "عليك السلام يا أمير المؤمين" Cara Abdullah menakwilkan ayat di atas dilatarbelakangi oleh dokrin mazhab mereka, yaitu: bada', raj'ah, tasbih, dan ghayba. Dalam menafsirkan ayat di atas, Abdullah bin Saba' menerapkan konsep tasybih. Ali ditasybihkan dengan Tuhan, segala yang terjadi dialam merupakan kehendak Tuhan. Oleh karena Ali diserupakan dengan Tuhan maka peristiwa alam adalah kehendak Ali dan itu merupakan gambaran keberadaannya $\mathrm{Ali}^{30}$

Kedua, Mazhab Fiqh; Al-Jash-Shash yang ahli fikih dalam mazhab Hanafi mengembangkan diskusi fiqh mengenai perbedaan pendapat sekitar "harta temuan" dalam menafsirkan QS. Yusuf ayat 26,

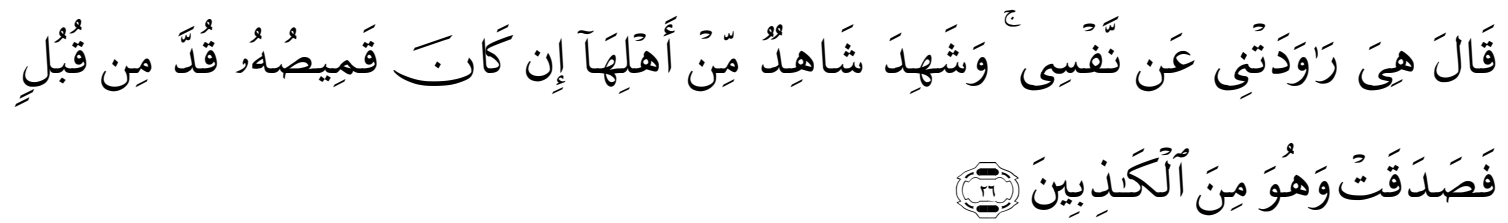

Artinya:"Yusuf berkata: "Dia menggodaku untuk menundukkan diriku (kepadanya)", dan seorang saksi dari keluarga wanita itu memberikan kesaksiannya: "Jika baju gamisnya koyak di muka, Maka wanita itu benar dan Yusuf termasuk orang-orang yang dusta”.(Q.S. Yusuf [12] : 26)

\footnotetext{
${ }^{27}$ Ignaz Goldziher, Mazhab-mazhab,...,hal. 193

${ }^{28}$ Abdullah bin Saba' adalahpendiriSyiahGhulat (ekstrim), dikatakanekstemkarena Abdullah bin Saba' seringmengemukakanpendapat yang dianggapekstrem, bahkanuntukkalangansyiah. Misal, merekapernahmengatakan Ali sebagaiTuhan, Ali sepantasnyamenjadiNabi. HarusNasution, Teologi Islam, (Jakarta: UI Press, 1986), h. 76

${ }^{29}$ Muhammad Husain al-Zahabi, al-Tafsirwa al-Mufassirun, jilid 2, (Kairo: MaktabahWahbah, t.th.), h. 11

${ }^{30}$ Abdul Razak\&Rosihan Anwar, IlmuKalam, ...,h. 107
} 
Diskusi yang dikembangkan misalnya, bagaimana hukumnya jika seseorang yang mengaku kehilangan barang, dan dia mampu menjelaskan tanda-tandanya. Bagaimana pula, jika yang hilang (al-laqith) itu adalah orang, lalu terjadi perselisihan antara dua orang yang merasa kehilangan, sementara orang yang satu dapat menjelaskan ciri-ciri tubuh anak yang hilang, dan yang lain tidak. Mana yang dimenangkan dalam kasus ini? Padahal ayat yang muncul sebagai kisah pribadi Nabi Yusuf yang sedang terlibat kasus dengan seorang wanita. Artinya tidak ada sangkut pautnya dengan masalah fiqh tentang harta temuan.

Berdasarkan contoh-contoh di atas, dapat disimpulkan bahwa dalam menafsirkan Alquran,mufasir sudah dipengaruhi oleh mazhab sehingga takwil yang mereka lakukan bukan berdasarkan makna asli dari salah satu ayat, tetapi lebih mengutamakan pandapat yang ada dalam mazhabnya. Ini berarti, ayat Alquran dibawa untuk membenarkan mazhab yang dianutnya. Jika didapatkan ayat yang tidak membenarkan mazhabnya, maka ayat tersebut ditakwilkan, walaupun dengan makna yang tidak sesuai dan terkesan memaksa.

\section{Kesimpulan}

Berdasarkan uraian di atas, maka dapat disimpulkan bahwa, tafsir partisan lahir dikarena kecendrungan para mufassir untuk mencari legitimasi mazhabnya atau mereka menafsirkan Alquran untuk membenarkan mazhabnya sehingga jika didapatkan ayat yang tidak sesuai dengan mazhabnya maka ayat tersebut ditakwil sesuai dengan mazhabnya. Akibat dari penafsiran bercorak ini menjadikan Alquran bukan lagi "rahmatan lil 'ālamīn" tetapi tidak lebih dari sebuah ideologi yang menguntungkan satu mazhab dan merugikan mazhab yang lain sehingga lahirlah tafsir-tafsir yang tidak sesuai dengan pesan Alquran itu sendiri. 


\section{DAFTAR PUSTAKA}

Abdul Mustaqim, Aliran-aliran Tafsir dari Periode Klasik hingga Kotemporer, Yogyakarta: Kreasi Wacana, 2005

Abdul Razak \& Rosihan Anwar, Ilmu Kalam, Bandung: Pustaka Pelajar, 2006

Abu Al-'Ala al-Mawdudi, Mabadi' Asasiyyat li Fah Alquran, terj. Khalil Ahmad alHamidi, cet. Ke-2, Jakarta: Al-Majlis al-'Ala al-Indunisi li al-Da'wat alIslamiyyat, 1999

Al-Mahalli, Jalaluddin dan Jalaluddin As-Suyuti, Tafsir Jalalain, Semarang: Toha Putra, t.th

Bagus Takwin, Akar-akar Ideologi, Pengantar Kajian Konsep Ideologi Dari Plato Hingga Bourdieu, Yogyakarta: Jalasutra, 2003

Harus Nasution, Teologi Islam, Jakarta: UI Press, 1986

Hasan Hanafi, Metode Tafsir dan Kemaslahatan Umat, Yogyakarta: Nawesea, 2007

Ignaz Goldziher, Mazhab Tafsir; dari Klasik hingga Modern, Terj. M. Alaika Salamullah, dkk., Yogyakarta: eLSAQ Press, 2006

Ignaz Goldziher, Mazhab-mazhab Tafsir, terj. M. Alaika Salamullah, dkk, Yogyakarta:Elsaq, 2006

Juliandi, Budi dan Herlambang, Saifuddun, "Menggugat Tafsir Tekstual", Jurnal AtTibyan, Vol. I Nomor 1 (Juni 2016)

Muhammad Husain al-Zahabi, al-Tafsir wa al-Mufassirun, jilid 2, Kairo: Maktabah Wahbah, t.th

Muhammad Yusuf,ddk., Studi Kitab Tafsir (Menyuarakan Teks yang bisu), Yogyakarta: Teras, 2004

Nashr Hamid Abu Zayd, Kritik Wacana Agama, Terj. Khoiron Nadhiyyin, Yogyakarta: LKiS, 2003

Nashruddin Baidan, Wawasan Baru Ilmu Tafsir, Yogyakarta: Pustaka Pelajar, 2005

Tim Prima Pena, Kamus Ilmiah Populer, Jakarta: Gramedia, tt 